\title{
Research on Ideal Education for Students in Southwest Petroleum University
}

\author{
Zhihua Zhang, Yunfeng Li \\ School of Mechanical Engineering, Southwest Petroleum University, Chengdu, China \\ Email:zzh20151118@163.com
}

Received 29 February 2016; accepted 27 March 2016; published 30 March 2016

Copyright (C) 2016 by authors and Scientific Research Publishing Inc.

This work is licensed under the Creative Commons Attribution International License (CC BY). http://creativecommons.org/licenses/by/4.0/

(c) (i) Open Access

\begin{abstract}
Ideal education for students in Southwest Petroleum University is an important aspect of the ideological and political education. The purpose of the ideal education is to establish college students' scientific world outlook, outlook on life and values of the important content. Based on the ideal of education for the significance of College Students' personal growth and social progress and development, the party and the government attach great importance to the ideal education for college students, all colleges and universities also the ideal education as a top priority of the ideological and political education of college students. This study reviews the history of ideal education in recent years, analyzes the effect of ideal education of college students factors and the existing problems of ideal education for college students. Based on the problems of ideal education for college students is presented: first, to raise awareness, to fully understand the importance of ideal education for college students, and actively carry out the action; Secondly, to clear the scientific outlook on development as guidance, to highlight the dominant ideology of the ideal education; to pay attention to the construction of campus culture, to build the harmonious humanistic environment; finally, to give full play to the advantages of university student party building work in education in ideals and beliefs of university students, in order to improve the effect of ideal education for college students.
\end{abstract}

\section{Keywords}

College Students, Ideal Education, Southwest Petroleum University

\section{Introduction}

The goal of middle school education is admitted to the University, finally is admitted to the University. Many students all of a sudden lost specific goals, even a student thinks that universities are the moment after years of studying and enjoying life, plus there is no academic pressure. Therefore, in the university campus, some stu- 
dents always late and sleep in class, talk and read novels (Hutyra, 2005). Look at them to spend the same age but wasted golden age life the most valuable, I feel very sad. Ideal education is a process of human-orientation, strength-inspiration and life-skill-reinforcement.

Many students because there is no scientific lofty ideal, in daily trifles inextricably bogged down in, got lost. Many students have higher pursuit, PubMed, not for academic contribution, just to be a life. For college students and graduate students, although they are adults, they still need the ideal education. Many of them think only of their work, the future, and few people will be self interests in global interests; few people will put the self value social welfare considerations. Therefore, they do not know why to read, confused, confused, and even kill Dutch act. Only the knowledge education of college students is far from enough, and students still need the ideal education. The ideal is still the spiritual pillar of their lives, and their life is the beacon. Based on the ideal education for college students, paying attention to methods and effects is very important to find a way to enable the students to accept. This article attempts to from the perspective of general education to students in Southwest Petroleum University find ideal education to strengthen college students' breakthrough, clear the connotation of the ideal education and general education concept. Analyzing the ideal education of contemporary college students a lot of achievements we will find that there are many problems, and has carried on the deep causes of the problems existing in the ideal education.

\section{Status and Problems of Ideal Education in Southwest Petroleum University}

The ideological and political education, as the main content of higher education in our country, the main content is the teaching of college students ideological transformation. In the pluralistic society, young college students with their sharp ideas, learn to accept new ideas, new ideas and creativity. Is this sensitivity to the new trend of thought, the contemporary college students of our country economy, social development has a unique experience and insights, they desire for knowledge and talent makes them actively engaged in the learning of new knowledge, and knowledge as the social impetus role have a more profound understanding. In addition, they break through the traditional knowledge, paying attention to the importance of social practice in the talent, actively participate in the construction of the great socialist cause. But as China's economic system reform, people's vision is more open, more active thinking. Influenced by all kinds of thoughts, the negative effects of some decadent and backward ideas and market economy still strongly impact higher education teaching idea, lead to some students lack the initiative construction consciousness actively and actively practice the ideals and beliefs of the lofty ideal and faith, which appeared in the loss of ideals, belief crisis, spiritual pillar collapsed, cannot adhere to the ideology of moral belief, in the face of difficulties, complacent, the practice test. A familiar phenomenon in the campus include: college students spiritual malaise, addicted to the game, high consumption, absent absent, cheating in exams, malicious arrears, suicide, or even illegal crime. Contemporary college students appear these problems in terms of ideals and beliefs, mainly due to the following reasons (Kim \& Richarme, 2009).

\subsection{The Erosion of Backward Thinking}

Due to historical reasons, China's feudal thought in quite a long time still exist, some feudal superstition and ignorance and backwardness of ideas in the new historical conditions still would be revived. Of contemporary college students' world outlook, outlook on life, values will produce negative misleading, extremely easy to corrosion has not yet formed a firm ideals and beliefs of the college students, in the certain degree to the ideological and political education of college students constitute the impact.

\subsection{The Influence of the Market Economy}

To establish public ownership as the mainstay of the market system, enhance the market resources of our country energy, but there have been many changes in performance of College Students' value in the market economy. Mainly in: a diversified market will inevitably bring about the main interest of diversification, which leads to the value subject and value realization path diversity; the two is the diversification of forms of social organization and development; the three is with the diversification of social economy, people's way of life from a single to diversified development trend, people's way of life is no longer in the same mode; the four is the employment of college students from a single model of the planned economy transition towards a diversified market model, the market has become the main way of regulating the employment of college students (Koilias, Kostoglou, Garm- 
pis, \& Van der Heijden, 2011). Nowadays, the college students are not only life in the ivory tower, is now the impact of economic and social environment, the concept of diversified economy impact on the value system of College of traditional, value orientation gradually diversified, so college students' ideological and political education facing new challenges.

\subsection{College Students' Ability to Resist the Temptation}

Some students mistakenly think that Marxism is a theory was founded in the $19^{\text {th }}$ century, is outdated today, cannot solve the current practical problems, so the fine tradition of the party, the party's basic knowledge enough, of Ideological and political education, the lack of learning enthusiasm and initiative. Some students thought difficult to resist all kinds of temptation, cannot distinguish between right and wrong, good and evil, beauty and ugliness, and will shake the faith.

They will be in the ideal and the reality, spirit and matter, between the group and the individual. Choose the latter, the neglect of the former, and think the spirit is dispensable, but money is indispensable, pay attention to material interests, ignoring the ideals and beliefs. It has also become an obstacle for the ideological and political education.

\subsection{The Western Hostile Forces of Chinese "Westernization" Policy}

Now the society is an information society, network has become college students generally contact tools, is for students to get information, an important means of communication, but also provides a platform for the rampant activities of Western hostile forces. Especially in recent years, with the continuous improvement of the opening degree of the network information, western culture input at the same time, through various forms of output value impact the ideological concept and value formation, the dross in the spread of western culture behind some Western civilization also through the spread of culture in China's domestic communication and awareness of college students impact. Especially in the contemporary, Internet technology developed, the openness of the dissemination of information also increased to eliminate the difficulty of the spread of Western dross, western culture by means of network carrier to impact our country to Marxism as the guiding ideology, this on our university education of ideals and beliefs threatened.

\section{The Methods to Carry out Ideal Education}

Now more and more students feel emptiness, depression and confusion, they even put the pursuit of material is regarded as the only goal of the pursuit of life, and that they did not establish lofty ideals have close relationship. One is to establish a scientific lofty ideal, the use of appropriate methods and counselors are inseparable for guidance.

\subsection{The Importance of Personal Ideal Education for College Students}

Ideal is the ideal society is a society made up of people, so the ideal education cannot do without people, this is the most basic reason. The individual is a social ideal commitment, social ideal is the ideal personal system integration. Ideal education for college students, it is necessary to guide college students to establish healthy and upward life ideal, professional ideal, ideal personality, but also to guide the students set up the Chinese characteristic socialism common ideal and lofty communist ideal. But if a person with lofty ideals and no specific personal ideal is not realistic, is of no significance. It is from this perspective, we are young to the education of the communist ideal is not to put the ideal of communism as a "heaven" login tickets to sell to the youth. The ideal should be students themselves, and this needs to be generated from real life.

\subsection{The Attention Level of Ideal Education, We Must Carry out the Ideal Education Step by Step}

From the ideal goal of education, ideal education for college students cannot bear, bear all the responsibility of the state and political education. From the point of view of the goal of ideal education, ideal education for college students could not bear to bear countries of ideal education for college students to achieve the most basic, the most important goal, first of all is education in the new era of college students should not muddleheaded, muddle along, no pursuit should choice the healthy life goal, the specific content of the ideal. Secondly is to so- 
cial development situation and social development need to combine, actively guide students to combine individual ideal and Chinese characteristic socialism common ideal, guide college students to establish the noble ideals make contributions for the cause of socialism with Chinese characteristics. The highest goal of ideal education for college students is explained by scientific socialism (communism) theory, to guide students to establish lofty ideals of communism, and for the dedication and even sacrifice (Lee \& Tai, 2008).

\subsection{Pay Attention to the Construction of Campus Culture, Building the Harmonious Humanistic Environment}

Harmonious, full of humanistic education environment is the best carrier of Ideological and political education work in Colleges and universities, inclusive and harmonious campus cultural environment is to loose, harmony, beauty as the foundation of the humanities atmosphere is a kind of invisible strength, can guide or constraints of human behavior. Through the campus environment, social environment, family environment to infiltration education and the humanity of ideological and political education, spiritual and philosophical characteristics into the life of college students, organic integration of school, family and social environment of Ideological and political education of external factors to become an open, three-dimensional, network education environment. Full of humanity environment of campus culture is reflected in the school system environment, interpersonal environment, teaching environment and classroom between teachers and students in the teaching environment. Are mostly embodied in the system of campus environment is guide and educate the students to improve the direction of development, rather than full prohibition bundle; interpersonal environment formed on emotion and personality equality, loose, lively interpersonal environment; teaching environment to allow students to participate in the, let the students involved in the process to think, to explore. In the service environment, set up full of humane environment, for students to provide quality educational services, to solve the ideological problems and solutions to the practical problems of combining, service to students learning, life and work, to recognize that students are not recognized, satisfaction, happy or not, whether it is conducive to student development in an all-round way, our ideological and political education work as the starting point and the home to return to (Lagrosen, Seyyed-Hashemi, \& Leitner, 2004). At the same time to find the breakthrough point, focused on solving the students are most concerned about, most closely related to the practical problems, students anxious anxious to students, objective facts and down-to-earth work to strengthen the ideological and political education of persuasion and appeal.

\subsection{Give Full Play to the Advantages of University Student Party Building Work in Guiding Educational Ideals and Beliefs of University Students}

The university student party building work is an important part of the work and the work of Party building, is the work of college students in strengthening the leading and plays a unique role to improve college students' ideal and belief education. Comrade Deng Xiaoping has repeatedly stressed: to the people, especially the young generation of ideal faith education. And points out that this is our modernization, an important weapon to overcome the difficulties and risks. In recent years, especially after the promulgation of the Twelfth National College Party construction work conference and <advice>, the University Party committee has taken effective measures in college students to strengthen the party's construction, college student party builds the job to showing a good momentum of development: a large number of young students care about politics, study the party's basic theory knowledge, enthusiasm, a positive move closer to the party organization, the number of increasing year by year, student party members' efforts to gradually increase, student Party member number is greatly improved, this to colleges and universities to strengthen college students' ideal and belief education created favorable conditions.

\section{Conclusion}

The counselor is an important part of higher school teachers and management team, and has dual identity of teachers and cadres. Counselors are the backbone to carry out ideological and political education of college students, college students ideological and political education and daily management work of the organizers, practitioners and instructors. Counselors should strive to become a college student mentor and the healthy growth of close friends. College counselor and teacher as a major force in the ideological and political education in Colleges and universities, directly face and contact with students thinking, learning, real life, and are not only the students' daily ideological and political education and management of workers, organizers and instructors and 
students' life teacher, are the healthy growth of the College students of the bosom friend, the ideological and political education of college students to the pivotal role, who play an irreplaceable role in guiding college students to establish correct ideals and beliefs is.

\section{References}

Hutyra, M. (2005). Quality Management System as the Part of University Management, Paper Presented at Integrating for Excellence, 15-17 June, Sheffield.

Kim, J. W., \& Richarme, M. (2009). Applying the Service-Profit Chain to Internet Service Businesses. Journal of Service Science and Management, 2, 96-106. http://dx.doi.org/10.4236/jssm.2009.22013

Koilias, C., Kostoglou, V., Garmpis, A., \& Van der Heijden, B. (2011). The Incorporation of Graduates from Higher Technological Education into the Labour Market. Journal of Service Science and Management, 4, 86-96.

Lee, J. W., \& Tai, S. W. (2008). Critical Factors affecting Customer Satisfaction and Higher Education in Kazakhstan. International Journal of Management in Education, 2, 46-59. http://dx.doi.org/10.1504/ijmie.2008.016230

Lagrosen, S., Seyyed-Hashemi, R., \& Leitner, M. (2004). Examination of the Dimensions of Quality in Higher Education. Quality Assurance in Education, 12, 61-69. http://dx.doi.org/10.1108/09684880410536431 